\title{
Copper slag as fine aggregate for high performance concrete
}

\author{
K. S. Al Jabri \\ Department of Civil and Architectural Engineering, \\ Sultan Qaboos University, Sultanate of Oman
}

\begin{abstract}
This paper presents results from an experimental investigation carried out to study the potential use of copper slag as fine aggregate on the strength of both normal and high strength concrete. Concrete mixtures were prepared using different proportions of copper slag as partial and full replacement of fine aggregate. The percentage of copper slag added by weight ranged between 10$100 \%$ of sand used in concrete. For each concrete mixture, six $150 \mathrm{~mm} \times 150 \mathrm{~mm} \times 150 \mathrm{~mm}$ cubes, three $300 \mathrm{~mm} \times 150 \mathrm{~mm}$ dia. cylinders and three $100 \mathrm{~mm} \times 100 \mathrm{~mm} \times 500 \mathrm{~mm}$ prisms were cast. Density, compressive, tensile and flexural strengths were determined at 28-day of curing. Cube compressive strength was also determined at 7-day of curing. Results demonstrated that there is general an increase in the density and workability of both normal and high strength concretes as copper slag quantity increases. Also results showed that the compressive strength of concrete is generally improved, compared with the control mix, with the increase of copper slag up to a certain copper slag content beyond which the strength generally reduces. Mixes with large copper slag percentage showed signs of bleeding and segregation due to the significant increase of workability.
\end{abstract}

Keywords: copper slag, fine aggregate, concrete, strength, workability, density.

\section{Introduction}

Aggregates are considered one of the main constituents of concrete since they occupy more than $70 \%$ of the concrete matrix. In many countries there is scarcity of natural aggregates that are suitable for construction whereas in other countries the consumption of aggregates has been increased, in recent years, due 
to the increase demand by the construction industry. In order to reduce dependence on natural aggregates as the main source of aggregates in concrete, artificially manufactured aggregates and artificial aggregates from industrial wastes provide an alternative for the construction industry. Therefore utilisation of aggregates from industrial wastes can be alternative to the natural and artificial aggregates.

Copper slag is an industrial by-product material produced from the process of manufacturing copper. It has been estimated that approximately 24.6 million ton of slag is generated from world copper industry $[1,2]$. In the Sultanate of Oman, approximately 60,000 tons of copper slag is produced every year by Oman Mining Company. Although the majority of the produced copper slag is used in the sand blasting industry and in the manufacturing of abrasive tools, the remainder is disposed without any further reuse or reclamation. There are many mechanical and chemical characteristics that qualify copper slag to be used in the concrete as partial replacement of Portland cement or a substitute of aggregates. For example, copper slag has number of favourable mechanical properties to be used as an aggregate such as excellent soundness characteristics, good abrasion resistance and good stability. Also, copper slag exhibits pozzolanic properties since it contains a low content of $\mathrm{CaO}$, and it can possesses cementitious properties as $\mathrm{CaO}$ content increases or under activation of $\mathrm{NaOH}$. Use of copper slag in concrete industry as replacement of cement or/and fine aggregates can have the benefit of reducing the costs of disposal and minimising environmental pollution $[1,2]$.

Little research work has been conducted to investigate the potential use of copper slag as fine aggregate on the properties of normal concrete. Akihiko and Takashi [3] investigated the use of slag from copper smelting as a fine aggregate in concrete. From mortar strength tests with a cement/slag/water ratio of $1 / 2 / 0.55$, the ball milled slag gave a higher strength. The effects of using several types of slag on mortar and concrete reaction, reinforcing steel corrosion, abrasion, workability and slump, shrinkage, and freezing and thawing characteristics were examined. The effect copper slag as replacement of fine aggregates on the strength, setting time and durability of concrete mixtures was also studied by Toshiki et al. [4]. Recently, Demirboğa and Gül [5] used blast furnace slag aggregates to produce high strength concrete. Different water/cement ratios were used to determine the 7- and 28-day compressive strength and other properties. Results showed that compressive strength of blast furnace slag aggregate concretes were approximately $60-80 \%$ higher than control concretes containing no slag for different water/cement ratios. It was concluded that blast furnace slag aggregate, in combination with other supplementary cementitious materials, could be utilised in making high strength concretes.

\section{Research objectives}

The main objective of this study was to investigate the use of copper slag as partial and/or full replacement for fine aggregate in normal and high strength concrete mixtures. The following were specific tasks: 
(1) Evaluate the effect of copper slag addition on the workability and density of normal and high strength concretes

(2) Conduct compressive, tensile and flexural strength testing on concrete mixtures

\section{Materials}

\subsection{Cement}

The cement used in this study was ordinary portland cement (OPC) purchased from Oman Cement Company. This cement is the most widely used one in the construction industry in Oman.

\subsection{Coarse and fine aggregates}

Coarse aggregates (i.e. $20 \mathrm{~mm}$ and $10 \mathrm{~mm}$ ) and fine sand were purchased from a nearby crusher in Al-Khoudh area, which are typically the same materials used in normal concrete mixtures. The gradation test conducted on aggregates showed that they met specifications requirements.

\subsection{Copper slag}

Copper slag is a by-product material produced from the process of manufacturing copper. As the copper settles down in the smelter, it has a higher density, impurities stay in the top layer and then are transported to a water basin with a low temperature for solidification. The end product is a solid, hard material that goes to the crusher for further processing. Copper slag used in this work was brought from Oman Mining Company, which produces an annual average of 60,000 tons.

\subsection{Silica fume}

The silica fume used in the production of high strength concrete was supplied and added to the mix in a powder form (Elkem Emsac 500s).

\subsection{Superplasticizer}

In order to improve the workability of high strength concrete, superplasticizer in the form of a polynaphthalene sulphonate-based admixture (conplast SP430) was used. This had $40 \%$ active solids in solution.

\section{Laboratory testing program}

\subsection{Mix design and sample preparation}

The mix proportions chosen for this study are given in Table 1 for both normal strength concrete (NSC) and high strength concrete (HSC). The constituents were weighed in separate buckets. The materials were mixed in a rotating pan in accordance with ASTM C192-98. The overall mixing time was about 4 minutes. 
The mixes were compacted using vibrating table. The slump of the fresh concrete was determined to ensure that it would be within the design value and to study the effect of copper slag replacement on the workability of concrete. The specimens were demoulded after 24 hours, cured in water and then tested at room temperature at the required age.

Table 1: Mix proportions and water-to-cement (w/c) ratios for normal and high strength concretes.

\begin{tabular}{|c|c|c|c|c|c|c|c|c|}
\hline \multirow[t]{2}{*}{ Type } & \multicolumn{6}{|c|}{ Mix proportions $\left(\mathrm{kg} / \mathrm{m}^{3}\right)$} & \multirow{2}{*}{$\begin{array}{l}\mathrm{w} / \mathrm{c} \\
\text { ratio }\end{array}$} & \multirow{2}{*}{$\begin{array}{c}\mathrm{SP} \\
1 / \mathrm{m}^{3}\end{array}$} \\
\hline & Cement & $\begin{array}{l}\text { Silica } \\
\text { fume }\end{array}$ & Sand & $\begin{array}{l}10 \mathrm{~mm} \\
\text { Agg. }\end{array}$ & $\begin{array}{c}20 \mathrm{~mm} \\
\text { Agg. }\end{array}$ & $\begin{array}{c}\text { Wat } \\
\text { er }\end{array}$ & & \\
\hline $\mathrm{NSC}$ & 416 & - & 721 & 338 & 790 & 207 & 0.5 & - \\
\hline HSC & 400 & 44 & 710 & 1190 & - & 140 & 0.35 & 7.9 \\
\hline
\end{tabular}

To determine the unconfined compressive strength, six cubes $(150 \mathrm{~mm} \times 150 \mathrm{~mm} \times 150 \mathrm{~mm})$ were cast for each mix and water-to-binder ratio, and three samples were tested after 7 and 28 days of curing. Three $150 \mathrm{~mm}$ diameter x $300 \mathrm{~mm}$ long cylinders were prepared for each mix in order to determine the 28-day tensile strength of concrete. Also, to determine the flexural strength (modulus of rupture) for each mix, three $100 \mathrm{mmx} 100 \mathrm{~mm}$ x $500 \mathrm{~mm}$ prisms were cast and tested after 28 days of curing.

\subsection{Testing procedure}

After curing, the following tests were carried out on the concrete specimens:

- 7- and 28-day cube compressive strength test was conducted in accordance with BS 1881: Part 116 using a loading rate of $2.5 \mathrm{kN} / \mathrm{s}$;

- 28-day cylinder tensile (splitting) strength test was done in accordance with ASTM C496-96 using a loading rate of $2 \mathrm{kN} / \mathrm{s}$; and

- 28-day flexural strength test was conducted in accordance with ASTM C78-94 using a simple beam with third point loading at a loading rate of $0.2 \mathrm{kN} / \mathrm{s}$.

All tests were conducted using a DARTEC compression machine.

\section{Test results and discussion}

The properties of normal and high strength concretes in terms of density, slump, compressive strength, tensile strength and modulus of rupture are shown in Tables 2 and 3, respectively.

The effect of copper slag addition as replacement of fine aggregate on the density of normal and high strength concretes is shown in Fig. 1. It can be seen from Fig. 1 that there is general increase in the density of both normal and high strength concretes with the increase of copper slag replacement in the concrete. The density of concrete was increased by almost $5 \%$ for both concrete types. This is mainly due to the higher specific gravity of copper slag which was 3.4 compared to fine aggregate which has a specific gravity of 2.8 . 
Table 2: $\quad$ Properties of normal concrete at 7- and 28-days of curing.

\begin{tabular}{|c|c|c|c|c|c|c|c|}
\hline \multirow{2}{*}{$\begin{array}{l}\text { Mix } \\
\text { No. }\end{array}$} & \multirow{2}{*}{$\begin{array}{l}\text { Mix } \\
\text { Type }\end{array}$} & \multirow{2}{*}{$\begin{array}{l}\text { Density } \\
\left(\mathrm{kg} / \mathrm{m}^{3}\right)\end{array}$} & \multirow{2}{*}{$\begin{array}{l}\text { Slump } \\
(\mathrm{mm})\end{array}$} & \multicolumn{4}{|c|}{ Strength (MPa) } \\
\hline & & & & $\left(\mathrm{F}_{\mathrm{cu}}\right)^{*}$ & $\left(\mathrm{~F}_{\mathrm{cu}}\right)^{+}$ & $\left(F_{t}\right)^{+}$ & $\left(\mathrm{F}_{\mathrm{cr}}\right)^{+}$ \\
\hline 1 & $\begin{array}{l}\text { Control } \\
(100 \% \mathrm{~S})\end{array}$ & 2524 & 50 & 33.2 & 44 & 3 & 7.7 \\
\hline 2 & $\begin{array}{l}10 \% \mathrm{CS}+ \\
90 \mathrm{~S}\end{array}$ & 2515 & 90 & 37.1 & 44.9 & 3.5 & 7.2 \\
\hline 3 & $\begin{array}{l}20 \% \mathrm{CS}+ \\
80 \% \mathrm{~S}\end{array}$ & 2540 & 90 & 39.6 & 48.5 & 3.7 & 7.2 \\
\hline 4 & $\begin{array}{l}30 \% \mathrm{CS}+ \\
70 \% \mathrm{~S}\end{array}$ & 2558 & 75 & 37 & 48.9 & 3.2 & 6.9 \\
\hline 5 & $\begin{array}{l}40 \% \mathrm{CS}+ \\
60 \% \mathrm{~S}\end{array}$ & 2550 & 145 & 36.2 & 48.1 & 3.8 & 6.5 \\
\hline 6 & $\begin{array}{l}50 \% \mathrm{CS}+ \\
50 \% \mathrm{~S}\end{array}$ & 2560 & 180 & 39.5 & 53.1 & 4.1 & 7.3 \\
\hline 7 & $\begin{array}{l}70 \% \mathrm{CS}+ \\
30 \% \mathrm{~S}\end{array}$ & 2601 & 185 & 37.2 & 46.6 & 3.6 & 6.3 \\
\hline 8 & $\begin{array}{l}90 \% \mathrm{CS}+ \\
10 \% \mathrm{~S}\end{array}$ & 2597 & 200 & 37.9 & 50.1 & 3.6 & 7.2 \\
\hline 9 & $\begin{array}{l}100 \% \mathrm{CS} \\
+0 \% \mathrm{~S}\end{array}$ & 2653 & 210 & 38 & 45 & 3.4 & 5.9 \\
\hline
\end{tabular}

$\mathrm{S}=$ Sand $\quad \mathrm{CS}=$ Copper Slag, $\quad *=$ Cured at 7 days $\quad+=$ Cured at 28 days.

Table 3: $\quad$ Properties of high strength concrete at 7- and 28-days of curing.

\begin{tabular}{|c|c|c|c|c|c|c|c|}
\hline \multirow{2}{*}{$\begin{array}{l}\text { Mix } \\
\text { No. }\end{array}$} & \multirow{2}{*}{$\begin{array}{l}\text { Mix } \\
\text { proportions }\end{array}$} & \multirow{2}{*}{$\begin{array}{l}\text { Density } \\
\left(\mathrm{kg} / \mathrm{m}^{3}\right)\end{array}$} & \multirow{2}{*}{$\begin{array}{l}\text { Slump } \\
(\mathrm{mm})\end{array}$} & \multicolumn{4}{|c|}{ Strength $(\mathrm{MPa})$} \\
\hline & & & & $\left(\mathrm{F}_{\mathrm{cu}}\right)^{*}$ & $\left(\mathrm{~F}_{\mathrm{cu}}\right)^{+}$ & $\left(\mathrm{F}_{\mathrm{t}}\right)^{+}$ & $\left(\mathrm{F}_{\mathrm{cr}}\right)^{+}$ \\
\hline 1 & $\begin{array}{l}\text { Control } \\
(100 \% \mathrm{~S})\end{array}$ & 2568 & 28 & 76.9 & 93.9 & 5.4 & 14.6 \\
\hline 2 & $\begin{array}{l}10 \% \mathrm{CS}+ \\
90 \mathrm{~S}\end{array}$ & 2530 & 28 & 79.6 & 99.8 & 5.2 & 13.6 \\
\hline 3 & $\begin{array}{l}20 \% \mathrm{CS}+ \\
80 \% \mathrm{~S}\end{array}$ & 2588 & 50 & 74.5 & 95.3 & 6.2 & 12.4 \\
\hline 4 & $\begin{array}{l}40 \% \mathrm{CS}+ \\
60 \% \mathrm{~S}\end{array}$ & 2586 & 125 & 64.8 & 79.6 & 4.6 & 10.8 \\
\hline 5 & $\begin{array}{l}50 \% \mathrm{CS}+ \\
50 \% \mathrm{~S}\end{array}$ & 2625 & 115 & 77.8 & 96.8 & 6.1 & 12.9 \\
\hline 6 & $\begin{array}{l}60 \% \mathrm{CS}+ \\
40 \% \mathrm{~S}\end{array}$ & 2658 & 128 & 69.0 & 83.0 & 4.8 & 11.1 \\
\hline 7 & $\begin{array}{l}20 \% \mathrm{CS}+ \\
80 \% \mathrm{~S}\end{array}$ & 2673 & 102 & 63.8 & 79.0 & 4.7 & 10.3 \\
\hline 8 & $\begin{array}{l}100 \% \mathrm{CS}+ \\
0 \% \mathrm{~S}\end{array}$ & 2700 & 150 & 63.4 & 82.0 & 4.4 & 10.1 \\
\hline
\end{tabular}

$\mathrm{S}=$ Sand $\quad \mathrm{CS}=$ Copper Slag, $\quad *=$ Cured at 7-days $\quad+=$ Cured at 28-days. 


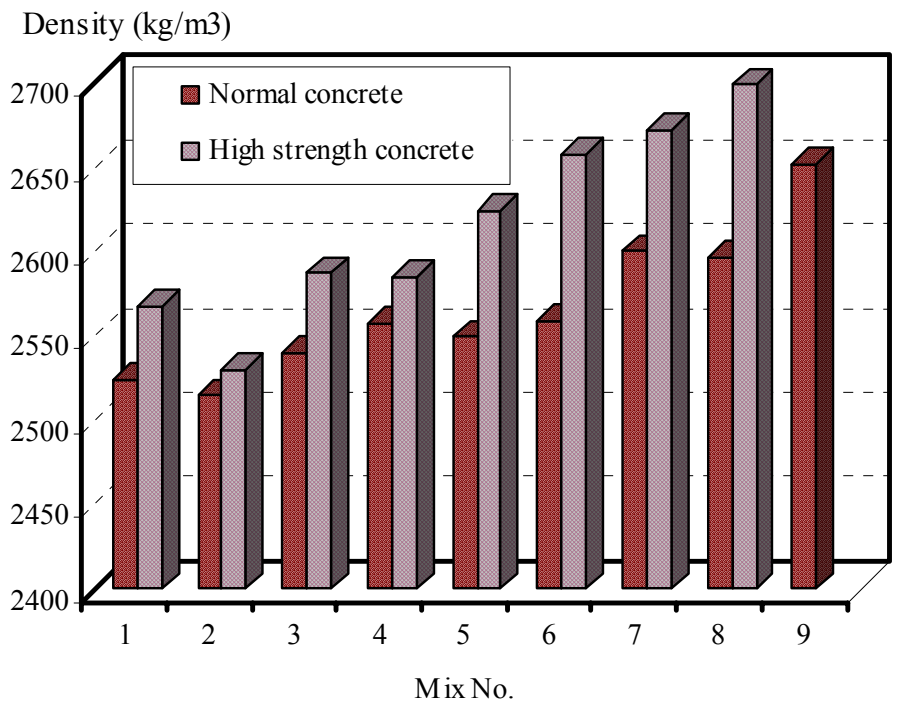

Figure 1: Effect of copper slag addition on the density of normal and high strength concrete

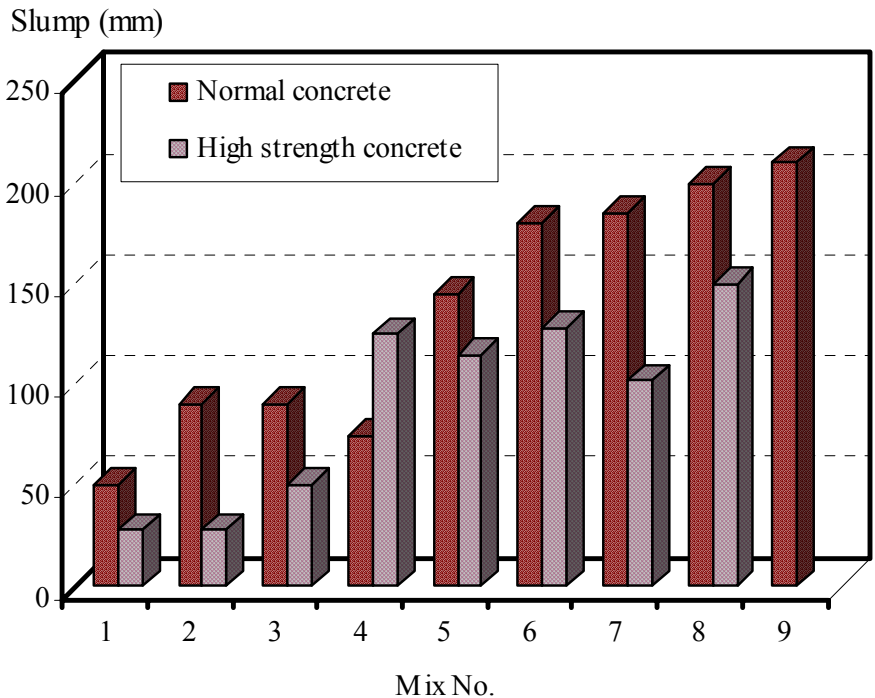

Figure 2: $\quad$ Effect of copper slag addition on the workability of concrete.

The workability of concrete was assessed based on the measured slump of fresh concrete as shown in Fig. 2 for different proportions of copper slag. It is clear from Fig. 2 that the workability of concrete increases significantly with the increase of copper slag in concrete mixes. For the control mix (i.e. mix 1), the 
measured slump was $50 \mathrm{~mm}$ and $28 \mathrm{~mm}$ for normal and high strength concretes respectively whereas for mixes 8 and 9 , with $100 \%$ replacement of copper slag for both NSC and HSC respectively, the measured slump was $210 \mathrm{~mm}$ and $150 \mathrm{~mm}$ for both types of concrete. This suggests that copper slag has much less absorption characteristics than sand which explains the considerable increase in workability as copper slag quantity increases. This increase in workability can have beneficial effect on concrete in the sense that concrete mixes with low water-to-cement ratios can be produced which can have good workability, greater strength and improved durability than conventional concrete. However, it should be noted that mixes with high contents of copper slag showed signs of bleeding and segregation of which can have detrimental effects on concrete performance.

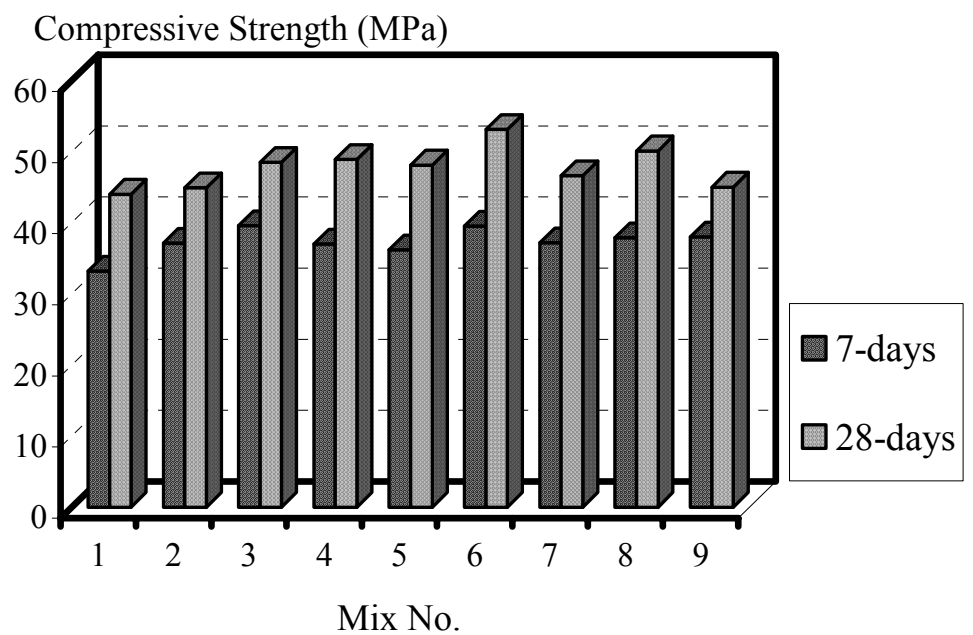

Figure 3: Average cube compressive strength of normal concrete at 7 and 28days of curing.

The average unconfined 7- and 28-days compressive strengths are shown in Figs. 3 and 4 for NSC and HSC, respectively. Results from both Figures show that the compressive strength of concrete is generally increases as copper slag quantity increases up to $50 \%$ addition of copper slag beyond which the compressive strength is slightly decreased due to the significant increase in the workability causing reduction in the strength. High water content in the mix causes the particles of the constituents to separate leaving pores in the hardened concrete which consequently reducing the strength. For normal concrete, Mix 6 (50\% sand and $50 \%$ copper slag) yielded the highest compressive strength value of $53 \mathrm{MPa}$ whereas the control mix gave a compressive strength value of 44 MPa. Mix 9 (with 100\% copper slag replacement) yielded a compressive strength of $45 \mathrm{MPa}$ which is comparable with the control mix (Table 2). For high strength concrete, the highest compressive strength was achieved by Mix 2 with $10 \%$ replacement of copper slag. The highest compressive strength was 
99.8 MPa compared with 93.9 MPa for the control mix. However, the mix with $100 \%$ replacement of copper slag (Mix 8) gave the lowest compressive strength value of approximately $82 \mathrm{MPa}$ which is almost $12.5 \%$ lower that the control mix (Table 3). Tables 2 and 3 indicate that the tensile strength of concrete and the modulus of rupture showed a similar behaviour to the compressive strength results.

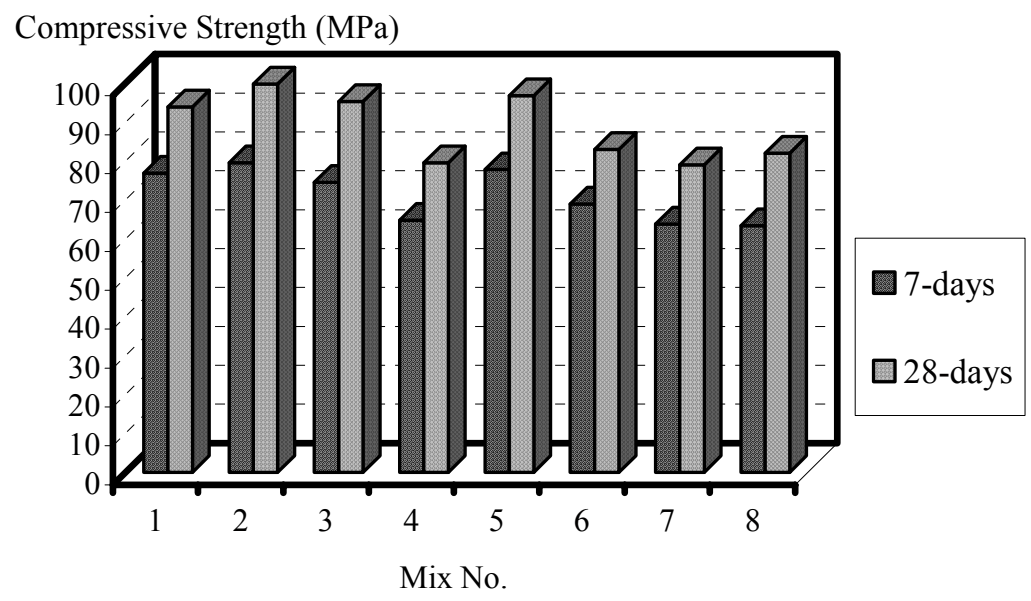

Figure 4: Average cube compressive strength of high strength concrete at 7 and 28-days of curing.

\section{Conclusions}

This paper presented the results of a research study on the effect of using copper slag as a substitute for fine aggregate in normal and high strength concrete mixes. Normal and high strength concrete mixes were prepared with different proportions of copper slag. Concrete mixes were tested for workability, density, compressive strength, tensile strength and flexural strength. Results showed that the increase in the copper slag content causes an increase in both workability and density of normal and high strength concretes. Results also showed that the compressive strength of concrete is generally improved, compared with the control mix, with the increase of copper slag up to a certain percentage beyond which the strength was slightly reduced. Mixes with large copper slag substitution suffered from bleeding and segregation due to the increase in workability. Generally it is concluded that copper slag can be used as fine aggregate to produce concrete with good strength.

\section{References}

[1] Shi, C., and Qian, J.; High Performance Cementing Materials from Industrial Slags - A Review. Resources, Conservation and Recycling, 29:195-207, 2000. 
[2] Gorai, P., Jana, R. K., and Premchand. Characteristics and utilisation of copper slag - a review. Resources, Conservation and Recycling; 39:299313; 2003.

[3] Akihiko, Y., and Takashi, Y. Study of Utilisation of Copper Slag As Fine Aggregate for Concrete (in Japanese). Ashikaya Kogyo Daigaku Kenkyu Shuroku; 23:79-85, 1996.

[4] Toshiki A, Osamu K, Kenji S. Concrete with copper slag as fine aggregate (in Japanese). J. Soc Mater Sci Jpn; 49:1097-102, 2000.

[5] Demirboğa, R., and Gül, R., Production of High Strength Concrete by Use of Industrial by-products, Building and Environment, in press, 2006. 